\title{
Methadone, Counselling and Literacy: A health literacy partnership for Aboriginal clients
}

\author{
STEPHEN BLACK, ANNE NDABA, CHRISTINE KERR AND \\ BRIAN DOYLE
}

\begin{abstract}
This paper describes a literacy program delivered at the Kirketon Road Centre (KRC), a primary health centre located in Kings Cross, Sydney. KRC was established to meet the health needs of 'at risk' young people, sex workers, and people who inject drugs. The literacy program was initiated from within an Aboriginal health group at KRC, following a request from clients in the group. A teacher from Tranby Aboriginal College delivered the literacy program one afternoon every fortnight over a period of approximately one year. This paper is based on recorded and transcribed 'reflection' discussions undertaken over several months between the literacy teacher, a KRC counsellor and the researcher immediately following the literacy sessions. Of particular interest is the nature of the literacy program and its pedagogical approach which is based largely on the delivery of popularly themed worksheet exercises. These activities represent in some ways an approach to adult literacy education that we term 'autonomous', that is, as a single set of skills generalisable to other life contexts. This pedagogical approach, however, needs to be understood in relation to the social capital outcomes of the course which take into account the complex and varying relationships and networks of the client group. The real value of the course can be seen largely in terms of the social capital outcomes for individual participants.
\end{abstract}

\section{Introduction}

This paper describes a literacy program delivered during 2007 at the Kirketon Road Centre (KRG), a primary health care facility established in 1987 to meet the health needs of 'at risk' young people, sex workers, and people who inject drugs in the Kings Cross area of Sydney (Kirketon Road Centre 2007). From the time of its establishment KRC adopted the Primary Health Care Philosophy (Stott 1983) encompassing concepts of acceptability, accessibility, affordability and equity of health service provision, under the World Health Organisation's (1978) banner of 'Health for All' (see Van Beek 2007: 330). 
Within KRC, an Aboriginal 'health and healing' group known as Itha Mari (a Barkindji word meaning 'this way: in the right direction') meets weekly. Clients from this group requested a literacy program to help them 'fill in forms', and the Aboriginal health project officer and counsellor initiated the literacy program in early 2007. The literacy program was delivered fortnightly at KRC for a 90 minute afternoon session with a literacy teacher employed by Tranby Aboriginal College in Glebe, Sydney. This literacy program was originally documented and analysed as a case study featuring as a minor component of a larger national research project on social capital and adult literacy partnerships (see Balatti, Black and Falk 2009a).The larger research project examined 'integrated' literacy and numeracy in partnerships in several sectors, one of which was health, and the project made recommendations for how adult literacy programs could move beyond educational institutions to be integrated with a range of public policy sectors. In the case study outlined in this paper we provide a more comprehensive account of the KRG program. The organisational partners involved an informal arrangement between $\mathrm{KRC}$ and Tranby Aboriginal College, with funding from a Commonwealth source, the Indigenous Coordination Centre (ICG). Literacy was 'integrated' in the sense that for some Aboriginal clients of the centre, the program was an element of a 'one-stop shop'. That is, clients attended the centre for medical and/or counselling support, to participate in the methadone access program, and/or for the literacy program as part of the activities of Itha Mari. This was integration in the physical sense that all activities were undertaken in the same building, but in a pedagogical and literacy content sense, the literacy class was 'stand-alone'. In other words, what was taught and discussed in the literacy class may have had little to do with the health functions of the centre, beyond that it may have assisted the general well-being of the participants. Thus the course differed from many 'health literacy' programs which usually focus on clients learning to manage health related written material.

The key aim of the research in the larger study and this KRC case study, was to examine the role of social capital, firstly at an organisational level in the form of partnerships, and secondly in terms of pedagogy, analysing the strategies of adult literacy teachers in drawing on and building social capital. In focusing on the pedagogy, this case study in an inner city health centre provides an example of the use of fairly traditional classroom activities mainly involving worksheet exercises based on popular interest themes. These activities can be viewed as an approach which largely represents an 'autonomous' concept of literacy. Drawing on the work of Street (1984, 1993), an autonomous concept sees literacy primarily in the singular, as a set of discrete skills that can be 
applied universally to a wide range of life contexts, and which usually represents in a formal schooling sense what it means to be literate. Often in the research literature a distinction is drawn between an autonomous concept of literacy and 'ideological' or socio-cultural understandings in which literacy is seen as a social practice, and given the wide range of literacy practices people encounter and use in their daily lives, leads to use of the term literacies (e.g. Baynham 1995, Barton and Hamilton 1998). Providing worksheet activities for Itha Mari clients was seen by the literacy teacher to be appropriate for meeting their literacy learning needs. However, while in a technical sense this pedagogy would appear to fit within an 'autonomous' approach to literacy, there are other elements of the pedagogy which accord with a social practice approach. As we will discuss later in the paper, improving literacy skills per se was not the prime object of the program. Rather, the literacy program aimed to provide the means for the achievement of broader social objectives by the client group, which we see largely in terms of social capital, and this aspect of the pedagogy can be associated with a social practice approach to literacy.

\section{Literature review}

The organisational site for this research, the $\mathrm{KRC}$, is innovative in its approach to community health, controversial at times in its history, and specific to the particular situation in the Kings Cross area of Sydney (KRC 2007). The factors at play in the literacy program under discussion in this paper were both complex and unique. These factors included the related but often distinct client groups - 'at risk' young people, sex workers, and people who inject drugs in the inner city of Sydney, together with their health needs, Aboriginality, cultural activities and literacy needs. In some urban western countries, and in particular the United States, Canada and Britain, there are many examples of health literacy partnerships involving health and adult literacy teachers working together (e.g. Hohn 1998, Rudd 2002, Nielsen-Bohlman, Panzar and Kindig 2004, Shohet 2004, Rootman and Gordon-El-Bihbety 2008, The Tavistock Institute 2009, Diehl 2011) though usually in contexts quite different to the one we focus on at KRC. There are also some examples of health literacy partnerships in Australia involving adult literacy teachers in health contexts, including programs in rehabilitation centres for recovering drug and alcohol addicts, but they are rarely documented (see Balatti, Black and Falk 2009b).

Ideally in health literacy programs, the teaching of literacy is 'embedded' or 'integrated' in the health context. Thus various literacy elements may be made explicit in the process of participants learning about health, that is, literacy is taught as 'an interrelated element of the same process' (Courtenay 
and Mawer 1995: 2) of learning about health, much in the way that integrated literacy approaches have been used in workplaces (McKenna and Fitzpatrick 2005) and other vocational education contexts (Black and Yasukawa 2011). In the study in this paper, the literacy program can be seen to be integrated with health not so directly in terms of its pedagogy, but in its role as part of an integrated health service provided to clients of the KRC.

As has been described, the key aim of the research was to examine social capital in adult literacy partnerships at both the organisational and pedagogical levels. Social capital is defined in this paper according to the Australian Bureau of Statistics [ABS] (2004:5) as: 'networks, together with shared norms, values and understandings which facilitate cooperation within and amongst groups'. This definition suggests social capital is very much about relationships within groups, which Portes (1998:7) makes clear: 'whereas economic capital is in people's bank accounts and human capital is inside their heads, social capital inheres in the structure of their relationships'.

The wide range of research literature on social capital indicates the contestability of the concept. There are issues, for example, relating to whether social capital applies to groups of people or whether it can be a resource held by an individual. Some researchers such a Bourdieu (1986) view social capital, along with other forms of capital (such as cultural or economic) as a resource used to reproduce the unequal distribution of power and goods within society. Others such as Putnam (2000) understand social capital to relate to cohesiveness in society, with increased memberships of social groups signifying greater social cohesion and healthier societies. This latter understanding is the one that more closely resembles the approach to social capital adopted in this study.

Usually social capital is considered to be beneficial (though not always, group memberships can have negative consequences). Commonly (e.g. Putnam 1990) social capital is viewed in terms of the nature of the connections or ties between people, including bonding ties - the strong ties that build cohesion and common purpose within a group; bridging ties which are weaker ties that are concerned with people accessing new networks with groups of people who are different from them; and linking ties which facilitate connections between individuals and various institutions and systems. Trust is often a key element of social capital (Fukuyama 1995).

In previous related research (Balatti, Black and Falk 2006, 2009), social capital was understood in relation to the ABS's (2004) conceptualisation, and the ABS social capital framework was adapted to indicate changes in social capital experienced by individuals in adult literacy programs. These can be seen in the right hand column of the framework in Table 1: 
Table 1 Indicators of social capital outcomes

\begin{tabular}{|c|c|c|}
\hline \multirow[t]{2}{*}{ Groupings } & \multirow[t]{2}{*}{ Elements } & Indicators for the study \\
\hline & & $\begin{array}{l}\text { Does participation in adult literacy and numeracy } \\
\text { courses result in }\end{array}$ \\
\hline \multirow{4}{*}{$\begin{array}{l}1 \text { Network } \\
\text { qualities } \\
\text { (including } \\
\text { norms and } \\
\text { common } \\
\text { purpose) }\end{array}$} & $\begin{array}{l}\text { Trust and } \\
\text { trustworthiness }\end{array}$ & 1a changes in trust levels? \\
\hline & Sense of efficacy & $\begin{array}{l}1 \mathrm{~b} \text { changes in beliefs about personal influence } \\
\text { on the student's own life and that of others? }\end{array}$ \\
\hline & \multirow{2}{*}{$\begin{array}{l}\text { Acceptance of } \\
\text { diversity and } \\
\text { inclusiveness }\end{array}$} & $\begin{array}{l}\text { 1c action to solve problems in the student's } \\
\text { own life or in that of others? }\end{array}$ \\
\hline & & $\begin{array}{l}\text { 1d changed beliefs and interaction with people } \\
\text { who are different from the student? }\end{array}$ \\
\hline \multirow{3}{*}{$\begin{array}{l}2 \text { Network } \\
\text { structure } \\
\text { (including } \\
\text { norms and } \\
\text { common } \\
\text { purpose) }\end{array}$} & Size & $\begin{array}{l}2 \text { a change in the number and nature of } \\
\text { attachments to existing and new networks? }\end{array}$ \\
\hline & $\begin{array}{l}\text { Communication } \\
\text { mode }\end{array}$ & $\begin{array}{l}2 \mathrm{~b} \text { change in the number or nature of the ways } \\
\text { that the student keeps in touch with others in their } \\
\text { networks? }\end{array}$ \\
\hline & Power relationships & $2 \mathrm{c}$ change in the nature of memberships? \\
\hline \multirow{2}{*}{$\begin{array}{l}3 \text { Network } \\
\text { transactions } \\
\text { (including } \\
\text { norms and } \\
\text { common } \\
\text { purpose) }\end{array}$} & Sharing support & $\begin{array}{l}\text { 3a change in the support sought, received or } \\
\text { given in the networks to which the student is } \\
\text { attached? }\end{array}$ \\
\hline & $\begin{array}{l}\text { Sharing knowledge, } \\
\text { information and } \\
\text { introductions }\end{array}$ & $\begin{array}{l}3 \mathrm{~b} \text { change in the ways the student shares } \\
\text { information and skills and can negotiate? }\end{array}$ \\
\hline \multirow{3}{*}{$\begin{array}{l}4 \text { Network } \\
\text { types } \\
\text { (including } \\
\text { norms and } \\
\text { common } \\
\text { purpose) }\end{array}$} & Bonding & $\begin{array}{l}\text { 4a changes in the activities undertaken with the } \\
\text { main groups with which they interact? }\end{array}$ \\
\hline & Bridging & $\begin{array}{l}4 \mathrm{~b} \text { changes in the activities with groups that are } \\
\text { different from the student? }\end{array}$ \\
\hline & Linking & $\begin{array}{l}4 \mathrm{c} \text { changes in the links that the student has to } \\
\text { institutions? }\end{array}$ \\
\hline
\end{tabular}

(from Balatti, Black \& Falk 2006: 17). 
In a study by Balatti, Black and Falk (2006) it was found that adult literacy courses resulted in social capital outcomes using the indicators in Table 1 , and these outcomes in turn could be related to indicators of socio-economic wellbeing, including health. An increasing number of other studies also indicate the interrelationships between education and social capital, and adult literacy in particular (e.g. Schuller and Field 1998, Falk, Golding and Balatti 2000, Balatti and Falk 2002, Tett and Maclachlan 2007, St.Clair 2008, Balatti and Black 2011, Taylor et al 2011). The follow-up study by Balatti, Black and Falk (2009a), which incorporated the literacy program described in this paper, focused on cross-sectoral partnerships and the pedagogical strategies that build on and develop social capital.

\section{Research methods}

The research approach in this KRC study was qualitative, based on semistructured interviews primarily between the researcher and the literacy teacher, and also at times involving two other participants in the literacy sessions - a KRC counsellor and the KRC Aboriginal health project officer. The interviews were essentially 'reflection' sessions undertaken immediately following the literacy class. They provided the opportunity to discuss and reflect on aspects of the preceding literacy session - the pedagogy - what worked, what did not work, along with the many other interpersonal and broader aspects of the sessions. Interviews usually took between 45 minutes and an hour, and they were tape recorded and later transcribed in full. In total ten recorded interviews were undertaken between late May and December 2007, predominantly at KRC, though one interview was at Tranby Aboriginal College. The literacy course itself began in February 2007 and concluded one year later.

The researcher was not present during the delivery of the sessions, only in the post session interviews with the teacher and KRC staff. There were reasons for this. The presence of an older, Anglo background male in the classroom where there may be few participants, all Aboriginal and often young female sex workers, undoubtedly would have influenced classroom dynamics. Interviews involving the researcher and participants outside of the classroom would have been similarly problematic. There was the possibility of the teacher or KRG staff undertaking interviews with clients, but this had the potential to compromise their existing professional roles as teachers and counsellors in a health centre where trust with clients was paramount. University research ethics procedures involving informed, written consent, and the use of tape recording 
devices added to the problematic nature of documenting the views of the clients, and the decision not to do so.

As stated previously, the larger research study of which this study was a part, was concerned primarily to document the experiences of adult literacy teachers involved in health literacy partnerships, and to identify teaching strategies seen to draw on and develop the social capital of the participants. The perspectives of the clients were not the main focus of the larger research study, and besides, as indicated above, in this KRG study it was not considered appropriate to interview the literacy program clients. (The health term 'clients' is used to describe participants in this paper, reflecting the health context). The Itha Mari group aimed to be as welcoming and encouraging as possible for its Aboriginal clients, and the whole ethos of the group was based on trust. Interviewing or even observing clients in relation to the literacy class had the potential, however minor, to disrupt that trust.

\section{Findings and discussion}

\section{The literacy program context}

The Itha Mari literacy classes at KRC did not conform to the regular structures and practices of formal adult learning. The sessions took place in a largish room within the centre, with one central table and chairs around it. There were no supporting facilities such as whiteboards. A 'regular' literacy class at the centre included between four and eight clients, but sometimes deciding just who was a participant in the class on a particular day was problematic, given the comings and goings of clients. The main room led to an outside balcony which was used by a number of clients, some involved in the literacy program, others not. Thus there could be people walking through the main room, and on being asked if they wish to join the class they might state, 'No, no I'm just going to have a smoke'. One of the clients brought along her dog, which added to the informal and relaxed atmosphere, and provided a good conversation topic. Disruptions to the flow of the sessions were frequent, and the 'integrated' nature of the literacy class within the overall role of the centre was demonstrated by the teacher stating that sometimes in the course of a session a doctor seeking a client would 'pop their head in and say "I'm ready for you now"".

Unlike more formal education contexts, there was no enrolment process or even a formalised course as such, and the teacher would bring along with her all the resources she thought she would need, trying to cater for the interests and levels of those who might attend that afternoon. This provided part of her 
rationale for her pedagogical approach using worksheets - to meet the varying needs and educational levels of clients.

In all the literacy sessions, in addition to the teacher and clients, also present was a KRC counsellor and the Aboriginal health project officer. Both of these KRC staff members knew the clients well and were well trusted and respected by members of the Itha Mari group. Their presence in the literacy class was to support the literacy teacher in her role, to refer clients to clinicians as required and to address any issues external to the literacy class which might arise. The two staff members engaged fully in the classroom exercises with the participants in the class.

\section{The participants}

All participants in the Itha Mari group are Aboriginal, and identification as 'Koori', a term used by south-eastern Australian Aboriginal people to define their collective Aboriginality, was confirmed through a chat with the Aboriginal Project Officer. Not surprisingly, given the life circumstances of clients of the centre, some had issues in their lives that affected their learning and their classroom dispositions in the literacy class. For example, the teacher provided a description of one client struggling with substance abuse: 'she can't concentrate ... she might listen and then throw in something, a contribution, and then she goes off into her own little world, and fix her mobile or whatever ...' On some occasions a client would arrive intoxicated which necessitated the counsellor's intervention. On other occasions, clients who were distressed were 'fast-tracked' into seeing a counsellor. Some clients were homeless, or without stable accommodation. The Aboriginal Project Officer described clients of the centre as 'very marginalised and discriminated against quite often in Kings Cross and elsewhere... nobody else wants to know you, except, you know, when they want to access the sex industry or drugs'. The Itha Mari, and the literacy class within it, comprised a non-judgemental welcoming space, described by the Aboriginal Project Officer as 'a chance to be treated like a normal human being in Kings Cross, for a bit of time out'.

\section{The learning activities}

Clearly, in light of the life circumstances of many of the clients, the learning activities in the literacy class were unlikely to follow the norms of formal adult learning in vocational education and training (VET) or other adult learning organisations. Yet, ironically, a formal learning context was what clients wanted and demanded. They wanted 'exercises' to complete that were to be handed in and marked by the teacher, 'and they want me to use a red pen' 
(teacher's comment). These demands seemed to represent the desire to return to the formal learning that the clients associated with their own schooling experiences, which in many cases may not have been successful or enduring. The literacy classes at KRC could be seen to be an opportunity for clients to make up for their past educational experiences, or at least a reminder of those days. As the teacher commented, the classes were largely about recognition 'that I've got these skills I haven't had to use for 20 years, and I've still got them'. To the teacher this was empowerment for the clients.

While 'filling in forms' was cited as a rationale for the literacy program, few classroom exercises focused on this element. Mostly the learning 'exercises' comprised short written stories based on themes of topical interest and amusement, followed by discussion and comprehension-type writing exercises including spelling and vocabulary. Newspaper articles such as 'the dog attacking the shark' were popular as 'animal stories are great' (teacher's comments). The exercises were generally quite short, and the teacher prepared several different ones to accommodate the varying educational levels that the clients were comfortable with. The key aim was to generate discussion, interest, engagement and enjoyment and newspapers were used as a deliberate tool to facilitate the process.

For the teacher this seemed a pragmatic pedagogical approach which met participant needs. It was what the clients asked for largely because, on the surface at least, it was perceived to accord with formal learning, 'and they enjoy it because it's something the rest of the world participates in' (teacher's comment). The teacher acknowledged that this approach to learning was different to what she practiced in her own educational institution (at Tranby Aboriginal College), but the circumstances here were different. She needed to have at the ready resources to meet the interest and educational levels of anyone who turned up that afternoon, and because of the transitory nature of the clients and just a 90 minute class every fortnight, it was unrealistic to expect anything more than a 'taste' of learning. The teacher explained, for example, that she did not focus on specific grammatical features because: 'I don't think the attention span is there, and I see it as very much an introduction to literacy classes, just have a taste of it, and it's up to them to take it where they want to go'. As such, the teacher acknowledged there was 'no literacy logic' to what she did beyond encouraging dialogue, interest and engagement amongst clients, and possibly in one sense, providing the opportunities of a formal learning environment. She had little expectation that the literacy skills of the clients could improve markedly in the context of her limited literacy program intervention. As she stated: 
You can't sort of say, 'oh look, now they can fill out forms ...' you should never be expecting that from these types of sessions. It's more about, well, they engaged in the learning process and it opened up options for them. Whether they want to take up those options or not is up to them ...

The predominant use of worksheet exercises, even though they were based on themes of topical interest, can be seen as a generic or 'autonomous' approach to literacy which does not accord generally with a 'social practices' pedagogy in which learning activities are usually focused on the students' everyday lives and the role of literacy and numeracy practices within them (see Appleby and Barton 2006). In this literacy program context, however, it was their everyday lives that the clients were keen to escape from ('for a bit of time out'). Nevertheless, it would be wrong to suggest that the everyday lives of participants played no role in the literacy program. Opinions freely expressed by the participants and sought by the teacher were a reflection of their everyday lives and valued in classroom discussions. Further, as we outline in the next section, there were strong 'social capital' outcomes for participants, and a focus on these outcomes fit within a social practice approach to literacy. Thus, the classification of the literacy program as either 'autonomous' or 'ideological' is problematic. It had features of both.

Before focusing on the other program aims and outcomes, mention needs to be made of one additional element to the literacy classes which we refer to later in this paper, the occasional excursions during the session times. The teacher took some students to the local museum to see an Aboriginal exhibition, and to Tranby Aboriginal College. As discussed later in this paper, there were both positive and negative implications to these excursions.

\section{The broader social aims of the literacy program}

When asked directly what the literacy program achieves, the literacy teacher stated:

Hopefully it's social, in terms of working in a group and you can see relationships forming. I can see bonding with each other, forming and strengthening relationships in a distrustful world. 
While acknowledging she knew little of their personal lives, the teacher speculated that there was little trust and much tension in the lives of the clients, and that the literacy program played a role in dissipating tensions. She stated:

I'm assuming they live in a cut-throat world out there ... battling substance abuse, everything else that goes with that, rejection by society, harassment by police. And even amongst each other there's not much trust, you know, when you bring drugs into play ... those feelings go out of the window ... I mean, you can see there's that tension there, and that tension appears to be dissipating.

\section{Trust and networks}

Despite the absence of trust in the lives of the clients outside of KRC, and the occasional absence of it in the literacy sessions, trust nevertheless permeated many aspects of the literacy program. The counsellor who worked with the Aboriginal health project officer to establish and maintain Itha Mari, and who invited the literacy teacher to start a program, had a long background working with Aboriginal people on social justice issues. She used to teach at Tranby Aboriginal College where, years previously, she had known the literacy teacher, and hence she had complete trust in the teacher she was inviting to deliver the literacy program. The literacy teacher in turn was accepted straight away by the clients because she was a known and trusted friend of the counsellor. The teacher also had her own trusted networks. A visit to the museum for example, resulted in part because the teacher knew the Aboriginal education officer at the museum, a previous student at Tranby who had gone on to study fine arts at university and then into museum work. The behaviour and attitude of the literacy teacher also had to reinforce the trust placed in her by the clients, and this could happen in small ways. For example, on one occasion the teacher was late to class, and she was very apologetic to the clients. The counsellor later recounted: 'clients really appreciated the fact you were sorry for being late', especially because a number of previously invited guest speakers to Itha Mari had cancelled their visits with little or no advance notice, which the clients perceived as lack of respect shown towards them. Tranby Aboriginal College was also trusted as an institution, reinforced by the connections of both the teacher and the counsellor: 'they've just heard about it for so long even if they've never been there, and they know people who have been to Tranby' (literacy teacher's comment). 


\section{Bonding, bridging and linking ties}

As indicated previously, the teacher said she could see friendship bonds developing between clients in her class. In one class she described how a dominant female client who said she could not read, heaped praise on another female client with much less confidence, but who could read well, 'and you could see straight away a bond was developing'. On other occasions clients would provide support to each other while working on written exercises ('I'll show you what to do sis' being a typical response). The teacher spoke of the cooperation amongst the client group:

They're very cooperative in the way they learn ... if they're engaging, they really are engaging and across the room to each other, so they help each other out. So if someone asks the question of the teacher, often the answer will come from another student, 'no, no you got it wrong there, it's like this, you know, and this happened to me' ... and it can end up a discussion amongst the students.

The teacher described her classroom context as 'like a social setting around learning, rather than a classroom setting where it's the teacher instructing'. Based on her long term experiences of teaching Aboriginal students, the teacher regarded the level of cooperation in the classroom, involving group work and the sharing of knowledge, together with respect for elders, as particular characteristics of an Aboriginal learning style.

There were, however, interpersonal tensions too, which was hardly surprising given the diverse client group, with occasional instances of clients dominating the teacher's attention in the classroom. There were also gender issues as a couple of male clients at times objected to one dominant (and incessantly talking) female client who stated she wanted the class to be a women's group. These types of issues, together with the transitory nature of participation in the literacy class made bonding ties over the longer term problematic. The Aboriginal health worker noted one additional factor that worked against bonding in the group, stating that over a period of about six months at Itha Mari a number of their 'core' members were now in prison. Cycles of incarceration were not uncommon within the client group.

Bridging ties which enable people to access new networks with different types of people were encouraged largely through the occasional excursions. As we have mentioned, excursions were made to the museum and to Tranby 
Aboriginal College. These visits were important in enabling the clients to feel part of the broader society. As the teacher stated:

I want them to think 'I'm not that marginalised by society, I can do this ...' It's like, 'I can pass it off here. No one's looking at me'.

For this group of clients, however, establishing these new linking networks was problematic partly because some of them felt very uncomfortable anywhere outside of their familiar Kings Cross area. The Aboriginal health worker explained that he once took a group of clients on a visit to a park just a 20 minute journey from Kings Cross, and the clients were immediately concerned about when they would be getting back. He stated: 'I couldn't believe it, we were just going for two hours ... severe anxiety being out of Kings Cross for two hours'. The teacher was in two minds about excursions. On the one hand she saw the benefits for clients of connecting with the broader society in ways that were culturally safe and respectful, broadening their life experiences. On the other hand, potentially the excursions caused divisions in the group because only some of the clients attended and others preferred to attend their regular literacy class at KRC.

The third type of ties, linking ties, relates to connections with institutions. The best example of linking ties as an outcome of the literacy program was attempts by the teacher to engage the clients with learning programs at Tranby Aboriginal College where the teacher was employed. The teacher spoke of establishing a literacy class at Tranby for one day a week that the clients could attend, in addition to the Itha Mari class. The difficulties, however, seemed to relate to the issue referred to above, the reluctance of the clients to move beyond the Kings Cross area. One initial trip to Tranby (several kilometres away) was planned, but only one student attended, accompanied by the Aboriginal Project Officer. The teacher commented, 'they said "we'll be there, oh yes", but to actually get people out of Kings Cross seems to be a big deal. I didn't think it would be'. On an individual basis, however, the teacher persisted, and she did take a client to Tranby, showed her the facilities, including the computers, and introduced her to the coordinator of the Aboriginal studies course. The plan was for the client to continue attending the literacy class at Itha Mari 'until she's comfortable to move across' (to Tranby). 
Methadone, counselling and I iteracy

\section{Conclusions}

Literacy programs conducted in a health context for 'at risk' young people, sex workers and people who inject drugs are undocumented in the research literature. In the program outlined in this paper, there were clearly several layers of complexity, making the program unique, and thus we need to be wary of drawing implications from it for other health literacy programs. While the partnership was certainly innovative, the program was discontinued after a little more than a year due in part to lack of sustainable funding.

As an 'Aboriginal' education program it is difficult to draw significant implications from the program, due partly to the many layers of complexity associated with the life circumstances of the clients. The role of social networks and the development of social capital generally feature strongly in this paper, and these aspects are seen to be key elements for the success of educational programs for Aboriginal people (e.g. Kral and Falk 2004). The teacher, very experienced in teaching Aboriginal students, commented on the 'Aboriginal learning style' of the clients - their level of cooperation for example, and sharing of knowledge.

As a 'health literacy' program this study is an example of health and literacy professionals working together in an integrated way both at an organisational and pedagogical level. But to reinforce a point made earlier, this literacy program was never designed to focus on health-related issues in the way that many health literacy programs do, such as assisting clients to better navigate the health system or understand health/medical literature. The link between health and literacy in this case study was more the physical location of a literacy class in the premises of a health organisation, an innovative approach which has implications for literacy programs in other health organisations, and indeed in sectors beyond health.

A literacy program such as this can cause educators to question measures of success for literacy programs. Currently in the Australian VET system, course success is measured by outcomes such as qualifications achieved and accredited course completions. In government sponsored jobseeker literacy programs, pre and post assessments are undertaken to measure the individual student's improvement in literacy and numeracy skills over the period of a course. All of these criteria however, have no place in the literacy program described in this paper. Not one of the clients of KRC was officially enrolled in a course, and the literacy program was not 'accredited' in any way. Further, from the comments of the teacher, taking into account the nature of the program and the circumstances of the client group, there was little expectation or aim that the 
literacy skills of the clients would change to any marked extent as a result of the program.

The activities in the literacy class, in particular the focus on worksheet activities, were a pedagogical response to trying to meet the diverse educational needs of the clients. The activities, while not intrinsically very educational, were meant primarily to engage and interest the clients in learning. From the point of view of improving literacy 'skills', it was recognised that the program was always very limited in developing these human capital outcomes. Moreover, as the teacher indicated, there were important social capital outcomes - trust and bonding in the group, and clients connecting with other agencies. In this respect the program constructed clients as members of networks (Balatti and Black 2011).

As we have indicated in this paper, it is difficult to classify the pedagogical approach to literacy in this program within the Street's $(1984,1993)$ theoretical dichotomy of 'autonomous' or 'ideological'. The focus on worksheets exercises fits a traditional 'autonomous' approach - teaching the one literacy which is expected to extend to other forms of literacy. But these workshop exercises were really more of a prompt to engage the interest of participants in learning, and often led to open-ended discussions, and as we have seen, social capital outcomes. Such an approach, engaging with the perspectives and lives of participants, is more in tune with a social practice approach to literacy. This serves to indicate some of the complexities in theoretically labelling and reducing literacy programs to one particular approach to literacy.

A weakness in this study has been the absence of the clients' own voices. We acknowledge that this undermines to some extent our findings, but by the same token, the process of documenting the voices of participants in interviews, as we indicated in the methods section, would have been problematic and had the potential to disrupt the trust which formed the basis of the literacy programs.

Those involved in the delivery of the literacy program, the literacy teacher,the KRG counsellor and the Aboriginal project officer had little doubt they were providing a program of value to the clients, though gains were often not immediately apparent and a longer term perspective was necessary. It may be at a future point in time, possibly years later, that a client of the literacy class may decide to undertake formal learning at the educational institution to which, during the literacy program, they had previously been introduced. There were some encouraging signs that this might happen. Self empowerment may also take longer to develop. For the facilitators, the delivery of the literacy program was largely a matter of social justice, of providing support and direction, 
confidence and acceptance to the clients seeking to find 'their way', which of course was what Itha Mari was, and continues to be, all about.

\section{References}

Appleby, Y and Barton, D (2006) Social Practice Pedagogy, National Research and Development Centre, London.

Australian Bureau of Statistics (ABS) (2004) Measuring Social Capital: An Australian framework and indicators, Information paper, cat.no.1378.0, ABS, Canberra.

Balatti, J and Falk, I (2002) Socioeconomic Contributions of Adult Learning to Community: A social capital perspective, Adult Education Quarterly, vol 52, no 4, pp 281-98.

Balatti, J. and Black, S (2011) Constructing Learners as Members of Networks, in Catts, R, Falk, I and Wallace, R eds, Vocational Learning: Innovative theory and practice, Springer, Dordrecht, pp 63-76.

Balatti, J, Black, S and Falk, I (2006) Reframing Adult Literacy and Numeracy Course Outcomes: A social capital perspective, National Centre for Vocational Education Research, Adelaide.

Balatti, J, Black, S and Falk, I (2009a) A New Social Capital Paradigm for Adult Literacy: Partnerships, policy and pedagogy, National Centre for Vocational Education Research, Adelaide.

Balatti, J, Black, S and Falk, I (2009b) A new social capital paradigm for adult literacy: Partnerships, policy and pedagogy - Support document, National Centre for Vocational Education Research, Adelaide.

Barton, D and Hamilton, M (1998) Local Literacies: Reading and writing in one community, Routledge, London.

Baynham, M (1995) Literacy Practices: Investigating literacy in social contexts, Longman, London.

Black, S and Yasukawa, K (2011) Working Together: Integrated language, literacy and numeracy support in vocational education and training, University of Technology, Sydney.

Bourdieu, P (1986) The forms of capital in Richardson, J ed, Handbook of Theory and Research for the Sociology of Education, Greenwood Press, New York, pp 241-58.

Courtenay, M and Mawer, G (1995) Integrating English Language, Literacy and Numeracy into Vocational Education and Training: A framework, TAFE NSW, Sydney.

Diehl, S (2011) Health Literacy Education Within Adult Literacy Instruction, New Directions for Adult and Continuing Education, vol 130, pp 29-41. 
Falk, I, Golding, B and Balatti, J (2000) Building Communities: ACE, lifelong learning and social capital, Adult Community and Further Education Board, Melbourne.

Fukuyama, F (1995) Trust: The social virtue and the creation of prosperity, Hamish Hamilton, London.

Hohn, M (1998) Empowerment Health Education in Adult Literacy: A guide for public health and adult literacy practitioners, policy makers and funders, National Institute for Literacy, Massachusetts.

Kirketon Road Centre [KRG] (2007). The Kirketon Road Centre: A report of KRC's work in the Kings Cross community 1987-2007, KRC, Sydney.

Kral, I and Falk, I (2004) What is all that learning for? Indigenous adult English literacy practices, training, community capacity and health, National Centre for Vocational Education Research, Adelaide.

McKenna, R and Fitzpatrick, L (2005). Integrated Approaches to Teaching Adult Literacy in Australia: A snapshot of practice in community services, National Centre for Vocational Education Research, Adelaide.

Nielsen_Bohlman, L, Panzar, A and Kindig, D, eds (2004) Health Literacy: A prescription to end confusion, Institute of Medicine, Washington DC.

Portes, A (1998) Social Capital: Its origins and applications in modern sociology, Annual Review of Sociology, vol 24, no 1, pp 1-24.

Putnam, R (2000) Bowling Alone: The collapse and revival of American community, Simon \& Schuster, New York.

Rootman, I and Gordon-El-Bihbety, D (2008) A Vision for a Health Literacy Canada: Report of the expert panel on health literacy, Canadian Public Health Association, Ottawa.

Rudd, R (2002) A Maturing Partnership, Focus on Basics, vol 5, Issue C, viewed 22 Oct $2011<$ www.ncsall.net/?id=771\&pid=247>

Schuller, T and Field, J (1998) Social Capital, Human Capital and the Learning Society, International Fournal of Lifelong Education, vol 17, no 4, pp 226-35.

Shohet, L (2004). Health and Literacy: Perspectives, Literacy and Numeracy Studies, vol 13, no 1, pp 65-83.

St. Clair, R (2008) Reading, Writing and Relationships: Human and social capital in family literacy programmes, Adult Basic Education and Literacy Fournal, vol 2, no 2, pp 84-93.

Stott, N.C.H (1983) Primary Health Care: Bridging the gap between theory and practice. Berlin Springer-Verlag.

Street, B (1984) Literacy in Theory and Practice, Cambridge University Press, Cambridge.

Street, B ed (1993) Cross-Cultural Approaches to Literacy, Cambridge University Press, Cambridge. 
Taylor, M, Kajganich, G and Pavic, I (2011) Making Sense of Social Capital Theory Through the Lens of Adult Learning, University of Ottawa, Ottawa.

Tett, L and Maclachlan, K (2007) Adult Literacy and Numeracy, Social Capital, Learner Identities and Self Confidence, Studies in the Education of Adults, vol 39, no 2, pp 150-167.

The Tavistock Institute (2009).Evaluation of the Second Phase of the Skilled for Health Programme: Final evaluation report, The Tavistock Institute, London.

Van Beek, I (2007) Case study: Accessible primary health care - A foundation to improve health outcomes for people who inject drugs, International Fournal of Drug Policy, vol 18, pp 329-332.

World Health Organisation (1978) Declaration of Alma-Ata, International Conference on Primary Health Care, Alma-Ata, USSR, 6-12 September 1978. 